\title{
Gastrointestinal capacity, gut hormones and appetite change during rat pregnancy and lactation
}

\author{
Michelle L Johnson ${ }^{\dagger}$, M Jill Saffrey and Victoria J Taylor \\ School of Life, Health and Chemical Sciences, The Open University, Milton Keynes, UK \\ Correspondence should be addressed to V J Taylor; Email: vicky.taylor@open.ac.uk \\ ${ }^{\dagger}(\mathrm{M} L$ Johnson is now at Warwick Business School, The University of Warwick, Coventry, UK)
}

\begin{abstract}
Pregnancy and lactation increase maternal appetite and adiposity, which in humans can lead to long-term body mass retention. Previous rat reproduction studies suggest that appetite-inhibiting gut hormone, peptide-YY (PYY), is elevated, despite hyperphagia also that gastrointestinal size increases. The present study characterised changes in orexigenic (appetite-stimulating) ghrelin and anorexigenic (appetite-inhibiting) PYY and glucagon-like peptide-1 (GLP-1), and gastrointestinal architecture during pregnancy and lactation, in matched fed and fasted plasma and gut tissue samples taken during the dark phase. Enteroendocrine cells were immunolabelled, and gut masses and lengths were measured. Fasted plasma ghrelin reduced during pregnancy: it was lowest by day 18, recovered to control values at parturition, then increased by the end of lactation. Ghrelin-immunoreactive stomach cells and stomach ghrelin concentrations were highest at birth, prior to the onset of lactation-associated hyperphagia. Plasma fed GLP-1 concentrations were elevated during pregnancy, and together with higher colon concentrations of PYY and GLP-1 during early lactation, they were associated with gastrointestinal tissue expansion, not satiety. Body mass increased during lactation, whereas white adipose tissue depots depleted. Extensive gut remodelling coincided with elevated colon concentrations of PYY and GLP-1. Modifications included stomach and caecum expansion, and duodenal, ascending and descending colon circumference increases, all peaking by day 10 of lactation; increased intestinal masses and lengths peaking at lactation day 10 for small intestine and lactation day 25 for large intestine. If these physical tissue increases persist post-partum, they could accelerate future nutrient assimilation and storage in dams, and may contribute to increased obesity risk.

Reproduction (2019) 157 431-443
\end{abstract}

\section{Introduction}

Pregnancy and lactation involve extensive maternal adaptation for foetal and neonatal growth and to build and replace maternal energy reserves. In rats, dam body mass increases start soon after conception (Cripps \& Williams 1975), partly by adipose tissue accumulation (Lopez-Luna et al. 1991, Pujol et al. 2006). Post-partum, body mass increases again, to above that of nonpregnant controls, despite $\sim 60 \%$ loss of adiposity by day 16 lactation (Naismith et al. 1982). Thus, maternal body composition changes, although has not been extensively studied.

Hyperphagia during rodent early pregnancy increases food intake by $20 \%$ (Crean \& Rumsey 1971, Trujillo et al. 2011), with peaks of 50-60\% (Cripps \& Williams 1975) compared to nulliparous controls. Maternal intake during lactation peaks during week 3 lactation to 250-300\% of controls (Crean \& Rumsey 1971, Cripps \& Williams 1975, Denis et al. 2004). Hyperphagia during lactation is supported by reduced leptin and decreased adiposity (Woodside et al. 2000) and although appetite increases occur, studies of changes in gut appetite-regulating hormones have so far produced conflicting results.

Ghrelin increases with fasting, elevating prior to feeding (Nakazato et al. 2001) and is suppressed by increased leptin in males (Ueno et al. 2004). In ad lib fed pregnant rats, Taylor et al. (2009) found total ghrelin in plasma and some gut tissues was not suppressed, despite increased leptin mid-pregnancy, whereas another study found ghrelin decreased (Shibata et al. 2004). During lactation in rats, Taylor et al. (2009) reported no difference in either plasma or tissue total ghrelin, whereas Shibata et al. (2004) found lower ghrelin and hypothalamic mRNA during lactation than late pregnancy, suggesting possible systemic reductions after birth. Inconsistencies may be due to non-standardised and/or physiologically inappropriate sampling times, such as during light periods for feeding studies, as rodents consume most food during the active dark phase. This study addressed these issues with dark phase sampling and looking closely at ghrelin-secreting cell location and abundance, to address previously conflicting findings. 
Satiety hormones PYY and GLP-1 have received less research interest than ghrelin. GLP-1 may have differential abilities to regulate food intake based on nutritional status, with limited effects when fasted (Ronveaux et al. 2014). Also, GLP-1 treatment during proestrus was detrimental to early pregnancy events (Outeirino-Iglesias et al. 2015). During rat pregnancy, plasma total PYY increased (Tovar et al. 2004, Taylor et al. 2009) and gradual increases were documented in descending colon and rectum (Taylor et al. 2009). Taylor et al. (2009) reported increased plasma PYY at day 5 lactation in rats, paralleled by increases in DC and rectum, also hypothalamic PYY mRNA (days $5+15$, Suzuki et al. 2014). It appears plausible that elevated PYY has an important role in rat lactation. Why a purported satiety hormone was elevated, despite pregnancy and lactation-associated hyperphagia, remains to be established. No studies have explored circulating or gut tissue GLP-1 during lactation, hence, the current focus.

Maternal adaptation during pregnancy and lactation in many animals involves Gl tract structural changes (Speakman 2008, Reiff et al. 2015) to accommodate large food intake increases, although the mechanisms involved are poorly understood. Stomach tissue mass has been documented to increase during pregnancy and peak by late lactation in rats (Cripps \& Williams 1975, Taylor et al. 2009) and mice (Campbell \& Fell 1964). The small intestine is most extensively studied (Cripps \& Williams 1975, Burdett \& Reek 1979, Datta et al. 1995) with documented increases of $27 \%$ length by late lactation, $140-150 \%$ mucosal epithelium mass, also surface area (Boyne et al. 1966, Penzes \& Regius 1985). Colon length increases with pregnancy, and mass with lactation (Cripps \& Williams 1975, Taylor et al. 2009). PYY, GLP-1 and GLP-2 are co-secreted from gut L-cells (Mojsov et al. 1986) and have been linked with gut growth (Drucker et al. 1996) and increased capacity for nutrient absorption (Brubaker et al. 1997, Ghatei et al. 2001), although not yet in reproduction. In adult female mice, PYY stimulated growth of both the small and large intestines in a dose-dependent manner, whereas colon size only increased at higher doses (Gomez et al. 1995).

The aim of this study was therefore to clarify and elucidate roles of ghrelin, PYY and GLP-1 during maternal adaptation. Samples of fed and fasted plasma were obtained from the same animals, taken in the dark phase, also from matched gut tissue, with PYY and GLP-1 concentrations measured for the first time during different reproductive stages. Comprehensive measurements have explored gut capacity and expansion in detail; thus, this study advances and updates the current knowledge of gut growth during pregnancy and lactation and allows investigation into potential relationships between gut peptides and intestinal remodelling.

\section{Materials and methods}

\section{Animals}

This work was licensed under the Home Office Animals (Scientific Procedures) Act 1986 and had approval from The Open University Ethics Committee. Rats were chosen for this study to obtain an adequate volume of blood for matched fed and fasted circulating hormone analysis, with matched tissue peptide comparisons. Female Wistar rats (Harlan, Bicester, UK; $n=49$ ) were housed in groups of three or four, with free access to standard rodent breeding diet (801730, Special Diets Service Essex, UK), water and bedding material. The animals were adjusted to 12-h reverse lighting conditions (lights off between 11:00 and 23:00 h) for a minimum of 2 weeks before study start, and then permanently housed under these conditions. All procedures were carried out during the dark phase, in contrast to most prior studies, so that samples were obtained when most physiologically relevant for natural feeding behaviour. There were seven experimental groups: days 4, 12 and 18 of pregnancy and days $0,5,10$ and 25 of lactation $(n=7$ per group). The time points used for sample groups were optimised based on the findings of Taylor et al. (2009).

The oestrus dance (Feder 1981) was used to accurately time-mate females for pregnancy time-points, and for some lactation time-points when appropriate females presented with the dance (Stramek et al. 2018). Dams for the lactation time-points had their litters standardised to $8 \pm 1$ each by day two postpartum. Pups remained with the dams throughout the study and had free access to the cage diet when they were able to reach it, from approximately 16 days of age. Dams used on the day of birth had their litters standardised shortly after birth, when a nest had been established, and were killed approximately $4-5 \mathrm{~h}$ after birth. Pregnant dams for lactation time-points were separated into their own cage with nesting material between days 18 and 20 of pregnancy.

Pregnant rats had an age range of 24-38 weeks and lactating rats 18-37 weeks by the end of the study. Data from a group of six proestrus nulliparous females (aged 34-37 weeks) were included as a reference point for the study, but the focus of this study was on the differences between the groups progressing through pregnancy and through lactation.

\section{Body mass and food intake}

Live body mass was recorded prior to tail bleed (below) and once again after the fasting period, before killing. Food intake was monitored in singly housed females by weighing their food hopper in the days immediately prior to birth and into lactation before the pups started eating solid food.

\section{Blood collection and preparation}

Fed blood samples were taken from a tail vein, between 12:00 and 13:00 h, under anaesthesia (isoflurane; IsoFlo, Abbott Laboratories) to minimise stress during collection, as optimised from an earlier study (Johnson et al. 2016). Lubrithal (VetXX Ltd, Stoke-on-Trent, UK) was applied to the eyes of the rats whilst under anaesthetic to prevent them from drying out and a spray-on dressing (OpSite, Smith \& Nephew Medical Ltd, 
Watford, UK) was applied to the tail tip after sample collection. Once conscious, females were immediately returned to their home cage in their established social groups (pregnancy) or with their pups (lactating).

Cage food was removed (access to water maintained) at 08:00 the following day prior to killing between 12:00 and 16:00 h. Rats were fully anaesthetised and decapitated, and a fasted blood sample was obtained from trunk blood. All blood was collected into EDTA coated tubes with additional protease inhibitor (aprotinin; Trasylol, Bayer plc, Reading, UK). All fed and $1 \mathrm{~mL}$ of fasted blood samples were immediately acidified by dilution at $1: 10$ in buffer $(0.1 \mathrm{M}$ ammonium acetate, $0.5 \mathrm{M} \mathrm{NaCl}, \mathrm{pH} 3.6$ ) as recommended for optimal peptide preservation and recovery (Stengel et al. 2009).

\section{Gastrointestinal tissue measurements}

The gastrointestinal (GI) tract was measured and sampled in several locations: stomach, small intestine (SI), caecum, large intestine (LI; ascending and descending colon). Measurements of gastrointestinal length were made by emptying the gut of contents and free-floating the tissue in PBS, taking care not to stretch the tissue. Masses were recorded after emptying the gut and blotting the tissue dry on tissue paper. Due to differences in early sample collection, small intestine wet weight has been excluded from analysis for the day 25 lactating dam group and the proestrus controls.

Stomachs were removed and mass was recorded after opening along the greater curvature and rinsing in PBS. Once weighed, the stomach incision was extended to cut the stomach in half; one half was snap frozen for peptide extraction (see below) and the body of the other half was fixed in $4 \%$ paraformaldehyde overnight, then rinsed in $3 \times 10 \mathrm{~min}$ PBS and placed in $30 \%$ sucrose at $4{ }^{\circ} \mathrm{C}$ for a minimum of $48 \mathrm{~h}$ until frozen in OCT for cryosectioning transversely at $10 \mu \mathrm{m}$. The small and large intestines were removed whole, emptied and wet weight and length recorded. The caecum was removed and treated similarly to the stomach (see above). Approximately $1 \mathrm{~cm}$ of mid duodenum, proximal ascending colon and proximal descending colon was removed for circumference measurements. Circumference measurements were standardised by measurement after 20-min incubation in PBS containing $10^{-6} \mathrm{M}$ nicardipine hydrochloride to maximally relax the smooth muscle. Nicardipine could not be used to standardise gut length measurements due to the possibility of it interfering with other methodologies (e.g. peptide extraction) that the tissue subsequently underwent; circumference measurements were taken from one small piece of tissue. In addition to gut measurements, all of the white adipose tissue (WAT) in the abdominal cavity was carefully removed and weighed.

\section{Gastrointestinal tissue preparation for radioimmunoassay}

Half of each stomach and $\sim 2 \mathrm{~cm}$ portion of mid-duodenum, mid-ascending colon and mid-descending colon were collected and immediately frozen on dry ice. Tissue samples were extracted in $1 \mathrm{~mL}$ of $0.5 \mathrm{M}$ glacial acetic acid per $100 \mathrm{~g}$ of tissue collected and boiled in a $100^{\circ} \mathrm{C}$ water bath for $20 \mathrm{~min}$. The liquid portion of the boiled samples was stored at $-20^{\circ} \mathrm{C}$ until assayed.

\section{Radioimmunoassay}

As all fed plasma collected was acidified (thereby diluted), this was analysed for each peptide. Fasted acidified plasma was used in ghrelin assays as recommended to stabilise the acyl peptide form, and for PYY and GLP-1 assays, neat un-acidified/ undiluted fasted plasma was used because concentrations of both of these peptides were expected to be lowest in the fasted state. All samples were analysed in duplicate and according to the manufacturer's protocol for total ghrelin, total PYY and total GLP-1 concentration using radioimmunoassay kits (Millipore). An Excel spreadsheet was used to calculate sample concentrations from the standard curve, adjusted for sample dilution, with internal controls (provided with the kit) confirming optimal assay performance. All samples were added to assays based on sample type, not by pregnancy or lactation stage.

\section{Total ghrelin}

Preliminary testing measured high concentrations of ghrelin in all samples, so they were diluted ten times by a reduction in sample volume in the assay tubes. Due to cost, fed plasma ghrelin was not measured as a previous study (Johnson et al. 2016) found no difference between fed and fasted concentrations. Stomach tissue extracts underwent an additional 1:250 dilution for pregnant and 1:400 for lactating dams. The mean intra-assay variation was $4.4 \%$ for plasma and $10.1 \%$ for tissue and the mean inter-assay variation was $2.07 \%$ for plasma and $9.95 \%$ for tissue.

\section{Total PYY}

Fasted plasma samples were added to the kits as suggested by the manufacturers' guidelines. Although fed plasma samples were analysed, the dilution effect of acidifying the samples caused peptide recovery issues so these data are not presented - see 'Discussion' for why the interpretation of fasted PYY sample concentrations are as equally valid as fed samples during pregnancy. For both pregnant and lactating dams, ascending and descending colon extracts were diluted 1:80 prior to addition to the assays. The mean intra-assay variation was $4.4 \%$ for plasma and $6.2 \%$ for tissue and the mean interassay variation was $2.9 \%$ for plasma and $7.71 \%$ for tissue.

\section{Total GLP-1}

Fasted non-acidified plasma samples were extracted and added to each kit as outlined in the assay protocol. Double the volume of fed acidified plasma was required to undergo the kit extraction protocol in order to bring these samples onto the linear part of the standard curve. Ascending colon samples were diluted 1:80 and descending colon samples were diluted $1: 70$. The mean intra-assay variation was $4.5 \%$ for plasma and 
$6 \%$ for tissue and the mean inter-assay variation was $9.4 \%$ for plasma and $3.4 \%$ for tissue.

\section{Immunofluorescence of stomach tissue}

Stomach sections were stained for total ghrelin peptide using a standard immunofluorescence protocol, with incubations carried out at room temperature. Briefly, slides were incubated with normal horse serum (10\%) for $90 \mathrm{~min}$, washed in PBS and incubated overnight with 1:800 goat anti-ghrelin antibody (Santa Cruz Biotechnology). After $3 \times 10$ min washes in PBS, a biotinylated horse anti-goat $\lg$ (Vector) at $6 \mu \mathrm{g} / \mathrm{mL}$ was applied for $120 \mathrm{~min}$, followed by a further wash step. The slides were then incubated with streptavidin fluorescein $(4 \mu \mathrm{g} / \mathrm{mL})$ for $120 \mathrm{~min}$ before a final wash step and were then cover-slipped using Citifluor (Agar Scientific, Stanstead, UK). Negative controls were antibody-dilution solution only, primary antibody only, secondary antibody only and streptavidin fluorescein only.

\section{Quantification of immunolabelled cell numbers}

Images were obtained using an Olympus BX fluorescence microscope. In order to perform a manual cell count of each immunoreactive (IR) cell, serial images were taken of the entirety of each section of tissue stained using a $\times 10$ objective lens and all IR cells were counted from these images. The programme Image J was used to aid manual cell counting, using the cell counter plugin to mark each IR cell in each image. In order to count these images blind, an online list randomiser (http:// www.random.org/lists/) was used to assign a random number to each animal number. Each image was then renamed using this random number and cell counting was completed before counts were un-blinded for statistical analysis.

\section{Statistical analysis}

Values represent mean \pm S.E.M. Statistical analysis was initially carried out using a one-way ANOVA with a Tukey post hoc test on normally distributed data (shown on figures with asterisks e.g. $\left.{ }^{*} P<0.05\right)$. Data not normally distributed were normalised by log transformation (e.g. GLP-1 AC, DC; caecum and large intestine wet masses). When data were not normally distributed and could not be normalised, a Kruskal-Wallis test was used, with subsequent pairwise comparisons (MannWhitney), with Bonferroni correction. A paired-samples t-test was used to compare plasma peptides in the fed and the fasted states and to compare peptide concentrations in different areas/regions of the colon. As the experimental design included multiple factors including fed and fasted status, different regions of the gut and different time-points during pregnancy and lactation, as well as a proestrus control, GLM univariate analysis was used to test for any interactions. Tukey post hoc tests were used to investigate the sources of interaction and are shown on Figs 1, 4, 5, 8, 9 and 10 with e.g. $a>b, P<0.001$ etc. to indicate significance between different pregnancy and lactation charts. Italicised $a>b$ are also used to differentiate from other significant interactions. All statistical tests were performed using IBM SPSS Statistics 24. $P<0.05$ was considered statistically significant.

\section{Results}

Ghrelin concentrations were suppressed during pregnancy and elevated by the end of lactation

All stomach tissue samples had higher total ghrelin concentrations than plasma samples $(P<0.001$; Fig. $1 C>A$ and Fig. 1D>B). GLM analysis found significant main (direct) effects of sample type (plasma/ stomach; $F(7,112)=2.470, P=0.023$ ) and stage (proestrus, pregnancy or lactation time-points; $F(1,112)=643.676$, $P=0.000$ ) and a significant interaction (joint effect) of sample type with reproductive stage $(F(7,112)=2.269$, $P=0.035)$.

\section{Plasma}

Fasted plasma total ghrelin during pregnancy remained consistently reduced $(F(7,49)=27.751, \quad P=0.001$; Fig. 1A) compared with proestrus controls and all stages of lactation (Fig. 1B). During pregnancy, ghrelin was significantly $(F(2,18)=3.767, \quad P=0.043) \quad$ less concentrated in day 18 pregnant (d18P) dams compared with day 4 pregnant dams (d4P). By the day of birth (dOL), fasted plasma ghrelin concentrations had increased back to control amounts, and by day 25 of lactation $(\mathrm{d} 25 \mathrm{~L})$ had significantly increased $(F(3,24)=4.546$, $P=0.012)$ further compared with $\mathrm{dOL}(P=0.023)$ and day 5 lactating (d5L; $P=0.017)$ dams (Fig. 1B).

\section{Stomach tissue}

During pregnancy, the amounts of ghrelin in stomach tissue varied within each dam group, but were reduced in comparison with proestrus controls $(P<0.014$; Fig. 1C), in $\mathrm{d} 12 \mathrm{P}(P=0.035)$. Stomach tissue ghrelin concentration was significantly (Kruskal-Wallis, $\left.\chi^{2}=10.057,3 \mathrm{df}, P=0.018\right)$ increased by d0L compared with d12P $(P=0.001)$ and $\mathrm{d} 18 \mathrm{P}(P=0.036)$ dams, with a later, significant decrease by $\mathrm{d} 25 \mathrm{~L}(P=0.025)$ (Fig. 1D). Although dOL dams had the highest concentration of ghrelin in their stomach tissue out of all of the lactating and pregnant dams, this concentration was similar to that found in the proestrus controls.

Ghrelin-immunoreactive (IR) cells in stomach tissue were found throughout the mucosa, predominantly so towards the mucosal-submucosal border, in all groups quantified: proestrus, day 12 pregnant $(\mathrm{d} 12 \mathrm{P})$ and dOL (Fig. 2A, B and C). There was no difference in the mucosal area of the stomach, nor in the mean maximum thickness of the mucosa of muscle layers. However, the ghrelin-IR cell density was significantly different between the sample groups $(F(2,17)=29.735, P<0.001)$ and increased significantly from the proestrus controls 

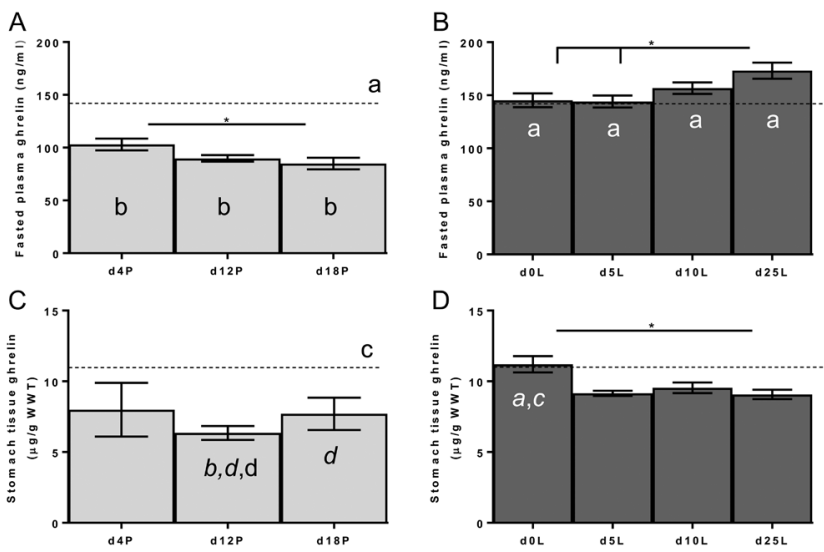

Figure 1 Concentrations of ghrelin in fasted plasma and stomach tissue throughout pregnancy and lactation. Fasted plasma ghrelin during (A) pregnancy $\left(* P<0.05 ; a>b,{ }^{* * *} P<0.001\right)$ and (B) lactation $\left({ }^{*} P<0.05\right)$; GLM: $(\mathrm{a}>\mathrm{b}, P<0.001)$; stomach tissue ghrelin during $(\mathrm{C})$ pregnancy $(\mathrm{c}>\mathrm{d}, P<0.05)$ and $(\mathrm{D})$ lactation $(* P<0.05)$; GLM: $(a>b$, $P<0.001, c>d, P<0.05)$. (d4P, day 4 pregnant, $n=7$; d12P, day 12 pregnant, $n=7 ; \mathrm{d} 18 \mathrm{P}$, day 18 pregnant, $n=7 ; \mathrm{d} 0 \mathrm{~L}$, day 0 of lactation, $n=7$; $\mathrm{d} 5 \mathrm{~L}$, day 5 of lactation, plasma, $n=7$; stomach tissue, $n=5$; d10L, day 10 of lactation, $n=7$; d25L, day 25 of lactation, $n=7$. Dotted line represents mean of proestrus controls, $n=6$.)

to $\mathrm{d} 12 \mathrm{P}$, and dams in the transition stage of parturition (dOL) had a significantly higher ghrelin cell density than in both the other sample groups (Fig. 2D).

\section{Peptide-YY (PYY) concentrations were increased during lactation}

All colon tissue samples had higher total PYY concentrations than plasma samples $(P<0.001$; Fig. $3 \mathrm{C}$, $\mathrm{D}, \mathrm{E}, \mathrm{F}>\mathrm{A}, \mathrm{B})$ and GLM analysis of colon region (ascending/descending) found significant main (direct) effects on colon tissue PYY of stage (proestrus, pregnancy or lactation time-points; $F(7,101)=4.701, P<0.001$; Fig. $3 C, D, E$ and $F$ with peak PYY concentrations at day 5 of lactation for ascending colon $(P=0.021$; Fig. 3D) and descending $(P=0.024$; Fig. $3 \mathrm{~F})$ colon compared with proestrus DC concentrations (Fig. 3F).

\section{Plasma}

Both the pregnant and lactating dams had similar fasted plasma total PYY concentrations, although they were elevated compared with proestrus controls in $\mathrm{d} 10 \mathrm{~L}$ dams $(F(4,35)=4.683, P=0.004$; Fig. $3 \mathrm{~A}$ and $\mathrm{B})$, with a tendency $(P=0.067$, n.s. $)$ in $\mathrm{d} 12 \mathrm{P}$ dams.

\section{Colon tissue}

Ascending and descending colon PYY concentrations varied considerably within each pregnancy group and were not significantly different from each other, although there was a numerical increase, especially in ascending colon, and PYY in the d18P dams in descending colon was two times higher than the proestrus controls (no ascending colon data), suggesting that PYY gradually elevated during pregnancy.

PYY concentrations in the ascending colon were significantly $(F(6,46)=3.215, P=0.011)$ highest in day 5 lactating $(\mathrm{d} 5 \mathrm{~L})$ dams - more than double - compared with the start of pregnancy $(\mathrm{d} 4 \mathrm{P}, P=0.025)$ and with the end of lactation (d25L, $P=0.021)$. Descending colon PYY concentrations were over three times higher in $\mathrm{d} 5 \mathrm{~L}$ dams than the proestrus controls (Kruskal-Wallis, $\chi^{2}=16.955,7 d f, P=0.018$ ).

\section{Glucagon-like peptide-1 peptide concentrations were suppressed in pregnancy when fasted and elevated when fed in pregnancy and lactation}

All colon tissue samples had higher total GLP-1 concentrations than plasma samples $(P<0.001$; Fig. 5 cf Fig. 4). GLManalysis found significant main (direct) effects on plasma GLP-1 of fed/fasted status $F(7,109)=5.208$, $P=0.000)$ and stage (proestrus, pregnancy or lactation time-points; $\quad F(1,109)=110.679, \quad P=0.000)$ and a significant interaction (joint effect) of fed/fasted status with reproductive stage $(F(7,109)=5.648, P=0.000)$.

\section{Plasma}

There was a large magnitude of GLP-1 differences between fed and fasted, as well as between pregnant, lactating and proestrus controls. Fed proestrus rats had twice the amount of circulating GLP-1 than fasted proestrus animals, but fed values were highly variable $(56 \pm 25.7$
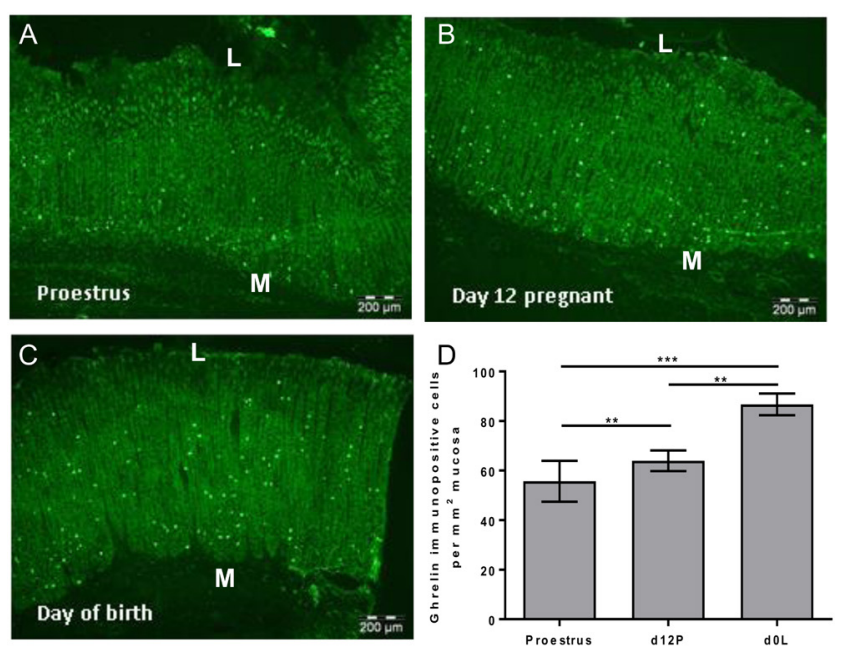

Figure 2 Representative images of stomach tissue (A, B and C) showing the distribution of ghrelin immunoreactive staining and (D) quantification of stomach tissue ghrelin cell density at proestrus, d12P and day of birth (dOL). L, luminal/mucosal surface; $M$, mucosal-submucosal border (proestrus, $n=6$; d12P, day 12 of pregnancy, $n=7$; d0L, day 0 of lactation, $n=7$. ${ }^{*} P<0.01$, $* * * P<0.001)$. 

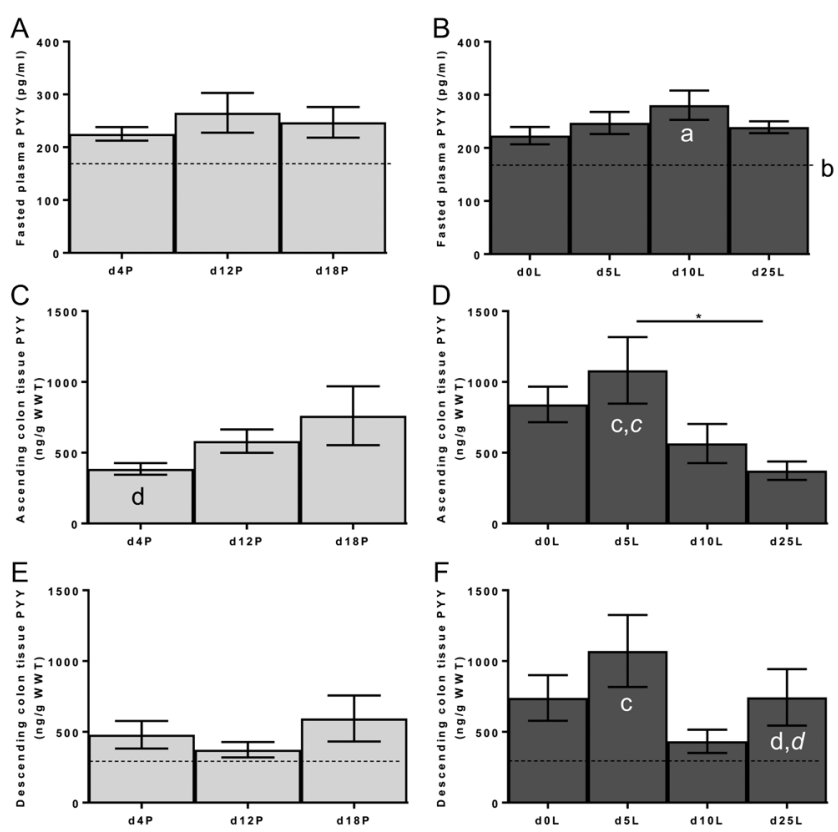

Figure 3 Concentrations of PYY in fasted plasma, ascending and descending colon tissues throughout pregnancy and lactation. Fasted plasma PYY in (A) pregnancy; and (B) lactation $(a>b, P<0.005)$; ascending colon PYY during $(C)$ pregnancy; and (D) lactation $\left({ }^{*} P<0.05\right)$; GLM: $(c>d, P<0.025)$; descending colon PYY during (E) pregnancy; and $(\mathrm{F})$ lactation $(\mathrm{c}>\mathrm{d}, P<0.025)$. GLM: $(\mathrm{c}>\mathrm{d}, P<0.025)$. (d4P, day 4 pregnant, $n=7 ; \mathrm{d} 12 \mathrm{P}$, day 12 pregnant, $n=7 ; \mathrm{d} 18 \mathrm{P}$, day 18 pregnant, $n=7 ; \mathrm{d} 0 \mathrm{~L}$, day 0 of lactation, $n=7 ; \mathrm{d} 5 \mathrm{~L}$, day 5 of lactation, $n=7$; d10L, day 10 of lactation, $n=7 ; \mathrm{d} 25 \mathrm{~L}$, day 25 of lactation, fed plasma, $n=6$; fasted plasma, $n=7$. Dotted line represents mean of proestrus controls, $n=6$; no control data for AC.)

cf $28 \pm 6.5 \mathrm{pg} / \mathrm{mL} ; P=0.368$, n.s.). During pregnancy, GLP-1 concentrations were significantly - approximately 28 times - higher $(t(20)=7.463, P<0.001)$ in fed plasma $(165 \pm 21.4 \mathrm{pg} / \mathrm{mL})$ than in paired fasted plasma $(6 \pm 1.1 \mathrm{pg} /$ $\mathrm{mL}$ ) (Fig. 4A cf 4C). For the whole lactating group, GLP-1 was five-fold more concentrated $(t(24)=5.502, P<0.001)$ in the fed state $(249 \pm 25.8 \mathrm{pg} / \mathrm{mL})$ than in the fasted state $(52 \pm 17.8 \mathrm{pg} / \mathrm{mL}$ ) (Fig. 4B cf 4D).

Fed plasma GLP-1 in pregnant dams did not significantly differ $(P=0.30$, n.s.) between groups, but was elevated $2-4$ times during pregnancy by d12 $(P=0.024)$ compared to proestrus fed nulliparous controls $F(3,23)=3.24, P=0.041$; Fig. $4 \mathrm{~A})$. In contrast, fasted plasma GLP-1 concentrations were significantly decreased at each stage of pregnancy $(F(3,25)=8.613$, $P<0.001)$ compared with proestrus fasted controls, starting at approximately three times lower in early pregnancy at $\mathrm{d} 4 \mathrm{P}$ until values were seven times lower by d18P (Fig. 4C) towards the end of pregnancy. Fasted plasma GLP-1 was significantly decreased during pregnancy $(F(2,18)=3.664, P=0.046)$, with a trend $(P=0.057$, n.s. $)$ for $\mathrm{d} 18 \mathrm{P}$ dams to have less fasted plasma GLP-1 than d4P dams.

Dams at the beginning of lactation had even higher $(F(4,26)=9.532, \quad P<0.001)$ fed plasma GLP-1 than
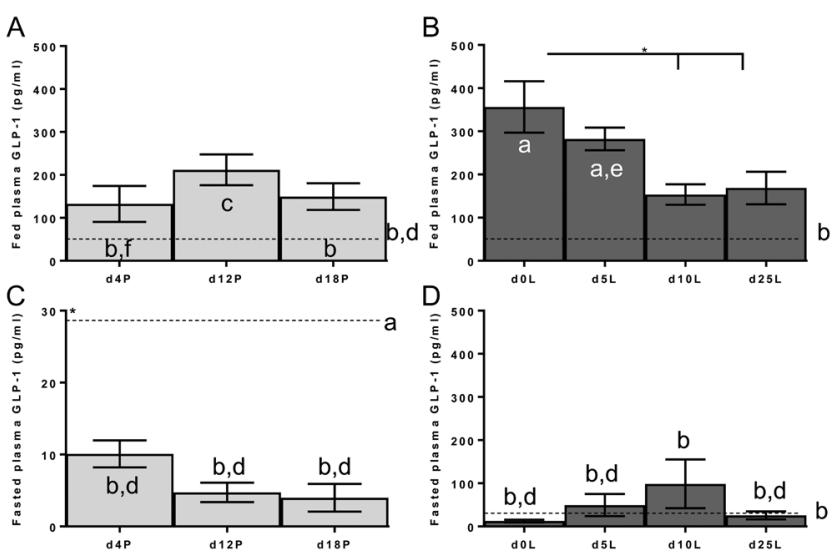

Figure 4 Concentrations of GLP-1 in fed and fasted plasma throughout pregnancy and lactation. GLP-1 in fed plasma during (A) pregnancy, $(\mathrm{c}>\mathrm{d}, P<0.025)$; and $(\mathrm{B})$ lactation $\left({ }^{*} P<0.05\right)$; GLM: $(\mathrm{a}>\mathrm{b}$, $P<0.001$; e $>$ f, $P<0.05)$; and GLP-1 in fasted plasma during (C) pregnancy $(\mathrm{a}>\mathrm{b}, P<0.001)$; and (D) lactation; GLM: $(\mathrm{a}>\mathrm{b}, P<0.001$; $\mathrm{C}>\mathrm{d}, P<0.025)$; note $y$ axes differences between figures $(\mathrm{C})$ and $(\mathrm{A})$, (B) and (D). (d4P, day 4 pregnant, $n=7 ; \mathrm{d} 12 \mathrm{P}$, day 12 pregnant, $n=7$; d18P, day 18 pregnant, $n=7$; d0L, day 0 of lactation, $n=7$; d5L, day 5 of lactation, $n=5$; d10L, day 10 of lactation, $n=7 ; \mathrm{d} 25 \mathrm{~L}$, day 25 of lactation, fed plasma, $n=6$; fasted plasma, $n=7$. Dotted line represents mean of proestrus controls, $n=6$.)

during pregnancy, that was approximately six-fold more than proestrus controls (Fig. 4B). Early lactation dams (d0L and $\mathrm{d} 5 \mathrm{~L}$ ) had higher fed GLP-1 values than in all the fasted and fed pregnant (except d12P fed, the third highest time point) and other lactating dams (Fig. 4A, C and D). There were no significant differences in fasted plasma GLP-1 during lactation and amounts were closer to proestrus controls (Fig. 4D).
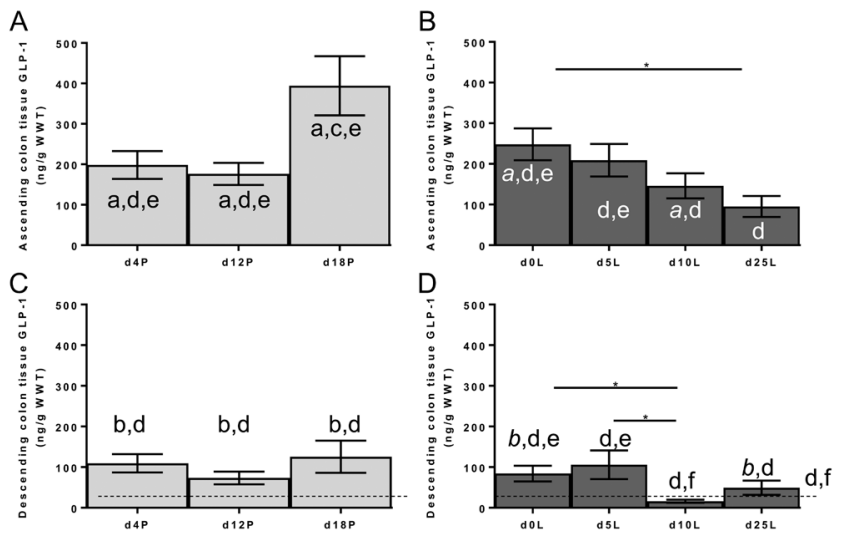

Figure 5 Concentrations of GLP-1 in ascending and descending colon throughout pregnancy and lactation. Ascending colon GLP-1 concentrations during (A) pregnancy and (B) lactation $\left({ }^{*} P<0.05\right)$; descending colon GLP-1 during (C) pregnancy; (D) lactation $(* P<0.05, \mathrm{e}>\mathrm{f}, P<0.05)$; $t$-tests: pregnancy $(\mathrm{a}>\mathrm{b}, P<0.01)$; lactation (a $>b, P<0.01)$; GLM: (c $>d, P<0.03$; e $>f, P<0.05)$. (d4P, day 4 pregnant, $n=7$; $\mathrm{d} 12 \mathrm{P}$, day 12 pregnant, $n=7$; d18P, day 18 pregnant, $n=7$; d0L, day 0 of lactation, $n=7 ; \mathrm{d} 5 \mathrm{~L}$, day 5 of lactation, $n=5$; $\mathrm{d} 10 \mathrm{~L}$, day 10 of lactation, $n=7$; d25L, day 25 of lactation, $n=7$. Dotted line represents mean of proestrus controls, $n=6$.) 


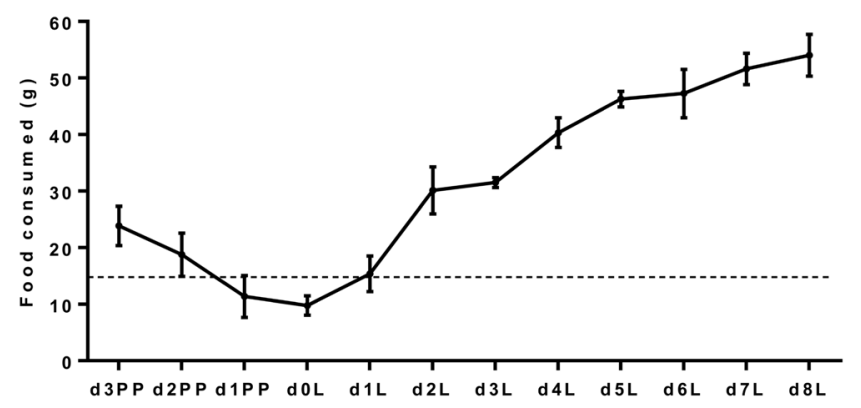

Figure 6 Food intake during the late peri- and early postpartum period. Dam food intake from 3 days PP until day 8 of lactation (d3PP-d1PP, days 3-1 peripartum; d0L-d8L, days 0-8 of lactation; $n=4$. Dotted line represents mean of proestrus controls, $n=6$ ).

\section{Colon tissue}

GLM analysis found significant main (direct) effects on GLP-1 concentrations of colon region (ascending/ descending) $F(1,104)=43.446, P=0.000)$ and stage (proestrus, pregnancy or lactation time-points; $F(7,104)=7.551, P=0.000)$ and a significant interaction (joint effect) of colon region with reproductive stage $(F(7,104)=2.637, P=0.016)$.

A comparison between different areas of the colon found that ascending colon concentrations of GLP-1 were significantly higher than those in descending colon tissue during all pregnancy time points (Fig. 5A and C; $\mathrm{d} 4 \mathrm{P} t(6)=5.224, P=0.002 ; \mathrm{d} 12 \mathrm{P} t(6)=4.466, P=0.004 ;$ $\mathrm{d} 18 \mathrm{P} t(6)=4.234, P=0.005)$. During lactation, ascending colon GLP-1 was higher than descending colon (Fig. 5C and D) at dOL $(t(6)=3.651, P=0.01)$ and $\mathrm{d} 10 \mathrm{~L}$ $(t(6)=4.369, P=0.005)$; therefore, GLP-1 concentrations in different regions of the colon were only similar at $\mathrm{d} 5 \mathrm{~L}$, due to a possible transient rise in descending colon; and they were also equivalent at $\mathrm{d} 25 \mathrm{~L}$ when GLP- 1 in both tissue regions had reduced to close to control values.

Within ascending colon, GLP-1 concentrations were significantly different between the pregnant dams $(F(2,18)=3.919, P=0.039$; Fig. $5 \mathrm{~A})$ and $\mathrm{d} 18 \mathrm{P}$ dams had twice the concentration of ascending colon GLP-1 than day 12 pregnant $(\mathrm{d} 12 \mathrm{P})$ dams, although this did not reach significance with ANOVA post hoc tests $(P=0.051$, n.s.). Descending colon tissue concentrations of GLP-1 were not significantly different with pregnancy stage, but were approximately two to four times higher than in proestrus controls (Fig. 5C).

Ascending colon GLP-1 concentrations decreased as lactation progressed and were significantly $(F(3,22)=4.164, P=0.018)$ higher in dOL dams than in d25L dams ( $P=0.016$; Fig. 5B). GLP-1 concentrations in descending colon tissue were significantly different $(F(3,22)=4.493, P=0.013)$ between the dam groups, and were highest at $\mathrm{d} 0 \mathrm{~L}$ and $\mathrm{d} 5 \mathrm{~L}$ before a sharp decrease by d10L $(P=0.020)$, with a significant decrease also found between $\mathrm{d} 0 \mathrm{~L}$ and $\mathrm{d} 10 \mathrm{~L}(P=0.030)$ dams
(Fig. 5D). Descending colon GLP-1 concentrations were higher at d0L and d5L $(P=0.001 ; P=0.036)$ than in the proestrus controls.

GLM analysis confirmed that GLP-1 concentrations in late pregnancy (d18P) ascending colon (Fig. 5A) were higher than all other time-points in both regions of colon ( $P=0.027-0.000$; Fig. 5B, C and D) and $\mathrm{d} 10 \mathrm{~L}$ $\mathrm{DC}$ concentrations (Fig. 5D) were lower than all the pregnant AC concentrations ( $P=0.047-0.000$; Fig. 5A), as well as d0 and d5L AC ( $P=0.016-0.000$; Fig. 5B).

\section{Peripartum food intake}

The four dams that could be monitored continuously for the most consecutive days around birth, halved their food intake from day 3 to day 1 prior to birth (Fig. 6). Food intake rapidly increased into the lactation period, doubling from $\mathrm{d} 1 \mathrm{~L}$ to $\mathrm{d} 2 \mathrm{~L}$. Food intake continued to increase and was highest at $d 8 \mathrm{~L}$, when monitoring stopped. The d8L dams consumed approximately $250 \%$ more than the mean daily food intake of all of the normally cycling nulliparous females $(15.5 \pm 0.09 \mathrm{~g}$, $n=43$ ) used in a prior study (Johnson et al. 2016).

\section{Changes in body and gastrointestinal size during pregnancy and lactation}

As expected, body mass significantly increased $(F(2,18)=12.565, P<0.001)$ with the advancing stages of pregnancy until birth (Fig. 7A). Body mass gain continued during lactation $(F(2,18)=12.942, P<0.001$;
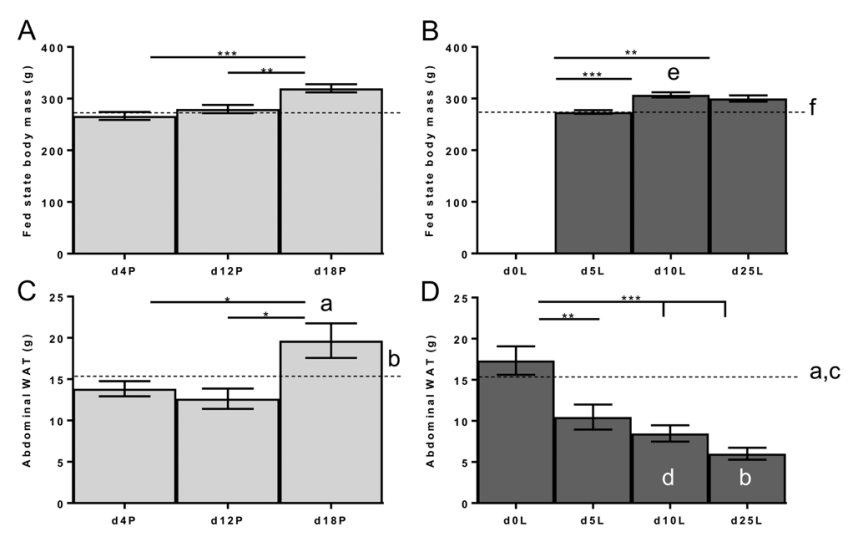

Figure 7 Changes in body mass and abdominal white adipose tissue mass throughout pregnancy and lactation. Changes in fed body mass during (A) pregnancy $(* * P<0.01, * * * P<0.001)$ and $(B)$ lactation $(* * P<0.01, * * * P<0.001$; e $>f, P<0.05$ ); (fed state is shown to avoid effects of short-term fast and dOL fed masses not shown as they include gravid uterus) and dissected WAT mass during $(C)$ pregnancy $\left({ }^{*} P<0.05 ; \mathrm{a}>\mathrm{b}, P<0.001\right)$ and (D) lactation $(* * P<0.01, * * * P<0.001$; $\mathrm{a}>\mathrm{b}, P<0.001 ; \mathrm{c}>\mathrm{d}, P<0.01)$. (d4P, day 4 pregnant, $n=7 ; \mathrm{d} 12 \mathrm{P}$, day 12 pregnant, $n=7$; d18P, day 18 pregnant, $n=7 ; \mathrm{d} 0 \mathrm{~L}$, day 0 of lactation, $n=7 ; \mathrm{d} 5 \mathrm{~L}$, day 5 of lactation, $n=7 ; \mathrm{d} 10 \mathrm{~L}$, day 10 of lactation, $n=7$; $\mathrm{d} 25 \mathrm{~L}$, day 25 of lactation, $n=7$. Dotted line represents mean of proestrus controls, $n=6$.) 
analysis excluding dOL as fed mass included gravid uterus; Fig. 7B) and body mass exceeded that of proestrus control rats $(F(7,47)=16.208, P<0.001)$ by $\mathrm{d} 10 \mathrm{~L}$ $(P=0.038)$. Mass of abdominal cavity white adipose tissue (WAT) was significantly largest $(F(2,18)=6.248$, $P=0.009$; Fig. $7 C)$ by $\mathrm{d} 18 \mathrm{P}$ and showed a significant decline after d0L $(F(3,24)=13.899, P<0.001$; Fig. 7D) until the end of lactation. Day 18 pregnant dams had higher abdominal WAT values than proestrus nulliparous controls, while control rats had up to three times more WAT $(F(7,49)=10.495, P<0.001)$ than rats at day 10 and day 25 of lactation $(P<0.009 ; P<0.001$; Fig. $7 C$ and $D)$.

\section{Stomach and caecum masses only increased during lactation, peaking d10L}

Stomach tissue wet mass did not change throughout pregnancy and remained similar to the controls (Fig. 8A). During lactation, stomach mass significantly increased (Kruskal Wallis, $\chi^{2}=15.015,3 d f, P=0.002$ ), becoming heavier than early pregnancy time points and control values by $\mathrm{d} 10 \mathrm{~L}$, and $\mathrm{d} 25 \mathrm{~L}$ dams had significantly heavier stomachs than $\mathrm{d} 0 \mathrm{~L}(P=0.018)$ and $\mathrm{d} 5 \mathrm{~L}(P=0.002)$ dams (Fig. 8B) and all pregnant groups $(F(7,48)=12.648$, $P<0.001)$.

Similarly, caecum wet mass did not change significantly during pregnancy (Fig. 8C), but was significantly $(F(3,24)=40.888, P<0.001)$ heavier in both the $\mathrm{d} 10 \mathrm{~L}$ and $\mathrm{d} 25 \mathrm{~L}$ dams than in the $\mathrm{d} 0 \mathrm{~L}(P<0.001)$ and $\mathrm{d} 5 \mathrm{~L}(P<0.001)$ dams (Fig. 8D) and all pregnant groups $(F(7,48)=12.648, P<0.001)$. Additionally, $\mathrm{d} 5 \mathrm{~L}$ dam caecum mass was heavier than in $\mathrm{d} 4 \mathrm{P}$ animals $(P=0.013)$.
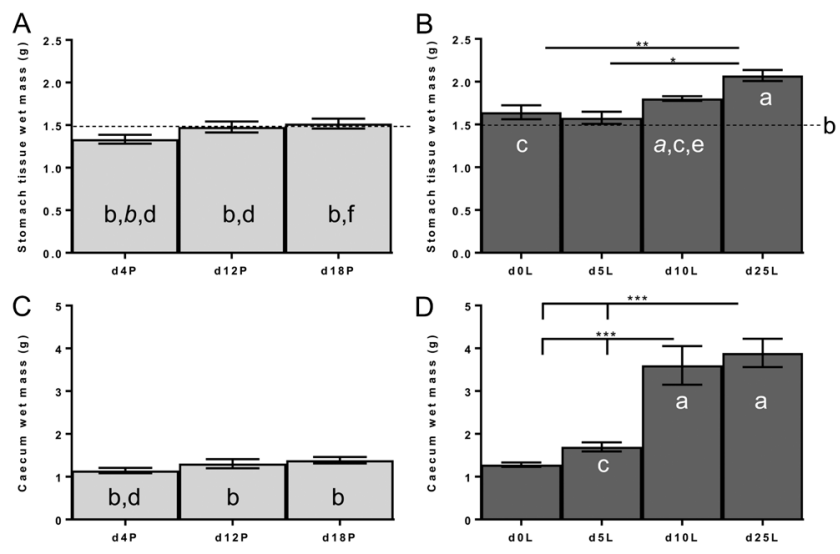

Figure 8 Stomach mass and caecum mass throughout pregnancy and lactation. Changes in empty stomach mass during (A) pregnancy and (B) lactation $(* * P<0.01 ; * P<0.05$; a $>b, P<0.001)$; $a>b, P<0.001$, $\mathrm{c}>\mathrm{d}, P<0.01$, e $>$ f, $P<0.05$; and empty caecum mass during $(\mathrm{C})$ pregnancy and (D) lactation ( $\left.{ }^{* * *} P<0.001\right)$; $\mathrm{a}>\mathrm{b}, P<0.001, \mathrm{c}>\mathrm{d}$, $P<0.02$. (d4P, day 4 pregnant, $n=7$; d12P, day 12 pregnant, $n=7$; d18P, day 18 pregnant, $n=7 ; \mathrm{d} 0 \mathrm{~L}$, day 0 of lactation, $n=7 ; \mathrm{d} 5 \mathrm{~L}$, day 5 of lactation, $n=7 ; \mathrm{d} 10 \mathrm{~L}$, day 10 of lactation, $n=7 ; \mathrm{d} 25 \mathrm{~L}$, day 25 of lactation, $n=7$. Dotted line represents mean of proestrus controls, $n=6$; no data for caecum: (C), (D).)

\section{Small intestine mass and length increased during pregnancy and lactation, peaking by $\mathrm{d} 10 \mathrm{~L}$}

Late pregnant, $\mathrm{d} 18 \mathrm{P}$ dams had significantly heavier $(F(2,18)=4.782, \quad P=0.022$; Fig. $9 \mathrm{~A})$ and longer $(F(2,18)=5.365, P=0.015$; Fig. 9C) small intestines than $\mathrm{d} 4 \mathrm{P}$ dams. Further growth continued during lactation: $\mathrm{d} 5 \mathrm{~L}$ dams had significantly heavier small intestines than dOL $(P=0.022)$ dams, and in mid-lactation, d10L dams had heavier $(F(2,18)=39.220, P<0.001)$ small intestines than both $\mathrm{d} 0 \mathrm{~L}(P<0.001)$ and $\mathrm{d} 5 \mathrm{~L}(P<0.001)$ dams (Fig. 9B); there were no data for d25L (see 'Methods' section). The small intestine also significantly increased in length in later lactation $(F(3,24)=17.944, P<0.001$; Fig. 9D), being significantly longer in both d10L dams (where peak growth had been reached) and $\mathrm{d} 25 \mathrm{~L}$ dams, than in d0L $(P<0.001)$ and $\mathrm{d} 5 \mathrm{~L}(P<0.001)$ dams. Day 10 and 25 lactation dams had approximately $48 \%$
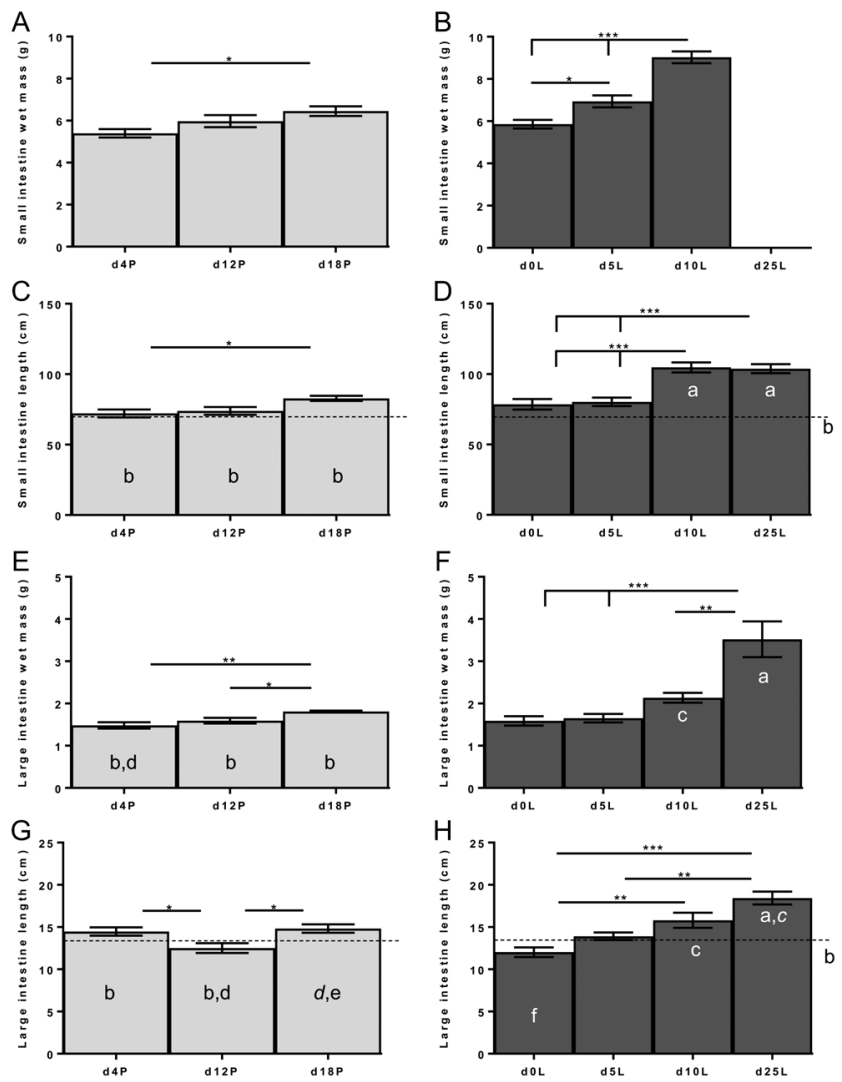

Figure 9 Changes in small and large intestine sizes throughout pregnancy and lactation. The mass $(A, B, E$ and $F)$ and length $(C, D, G$ and $H)$ of the small $(A, B, C$ and $D)$ and large $(E, F, G$ and $H)$ intestines during pregnancy and lactation. ${ }^{*} P<0.05,{ }^{* *} P<0.01$, *** $P<0.001 ; \mathrm{a}>\mathrm{b}, P<0.001, \mathrm{c}>\mathrm{d}, \mathrm{c}>\mathrm{d}, P<0.01$, e $>\mathrm{f}, P<0.05$. There were no data for small intestine masses at $\mathrm{d} 25 \mathrm{~L}$ or proestrus controls for small and large intestine masses. (d4P, day 4 pregnant, $n=7$; $\mathrm{d} 12 \mathrm{P}$, day 12 pregnant, $n=7$; d18P, day 18 pregnant, $n=7$; dOL, day 0 of lactation, mass, $n=4$; length, $n=7 ; \mathrm{d} 5 \mathrm{~L}$, day 5 of lactation, $n=7$; d10L, day 10 of lactation, $n=7 ; \mathrm{d} 25 \mathrm{~L}$, day 25 of lactation, mass, $n=5$; length, $n=7$. Dotted line represents mean of proestrus controls, $n=6$.) 

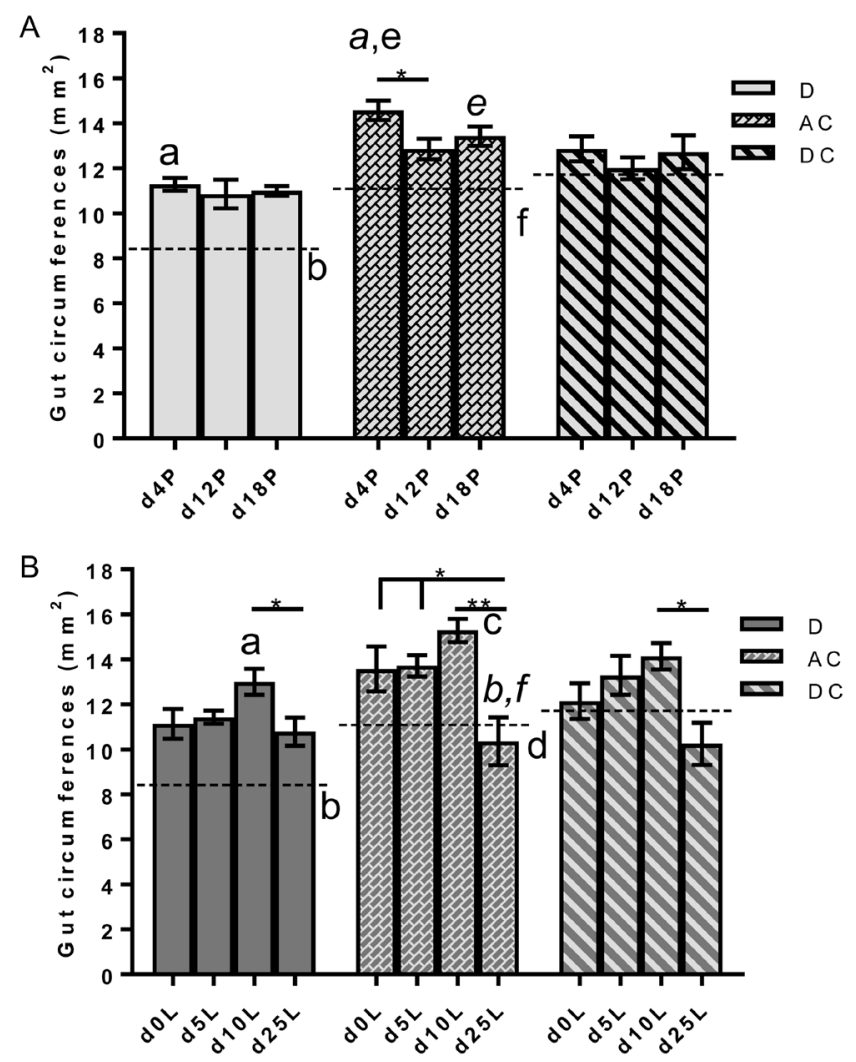

Figure 10 Changes in gut circumference throughout pregnancy and lactation. Changes in duodenum (D), ascending colon (AC) and descending colon (DC) circumferences during (A) pregnancy and (B) lactation. ${ }^{*} P<0.05,{ }^{* *} P<0.01 ; \mathrm{a}>\mathrm{b}, \mathrm{a}>b, P<0.001, \mathrm{c}>\mathrm{d}, P<0.01$, e $>f, e>f, P<0.05$. (d4P, day 4 pregnant, $n=7 ;$ d12P, day 12 pregnant, $n=7$; d18P, day 18 pregnant, $n=7 ; \mathrm{d} 0 \mathrm{~L}$, day 0 of lactation, $n=7 ; \mathrm{d} 5 \mathrm{~L}$, day 5 of lactation, $n=7 ; \mathrm{d} 10 \mathrm{~L}$, day 10 of lactation, $n=7$; $\mathrm{d} 25 \mathrm{~L}$, day 25 of lactation, $n=7$. Dotted line represents mean of proestrus controls, $n=6$.)

longer small intestines than proestrus controls, dOL and $\mathrm{d} 5 \mathrm{~L}$ dams and all pregnant groups $(F(7,49)=20.546$, $P<0.001)$.

\section{Large intestine mass increased during pregnancy and lactation, with length only increased by late lactation, peaking $d 25 L$}

Large intestines of $\mathrm{d} 18 \mathrm{P}$ dams were significantly heavier $(F(2,18)=7.931, P=0.003$; Fig. $9 \mathrm{E})$ than the $\mathrm{d} 4 \mathrm{P}$ $(P=0.003)$ and $\mathrm{d} 12 \mathrm{P}(P=0.046)$ groups, although they were significantly $(F(2,18)=5.506, P=0.014)$ shorter in d12P dams than in $\mathrm{d} 4 \mathrm{P}(P=0.044)$ and $\mathrm{d} 18 \mathrm{P}(P=0.017)$ dams (Fig. 9G). Dams at the end of the lactation period (d25L) had significantly $(F(3,19)=19.322, \quad P<0.001)$ heavier large intestine tissue than d0L $(P<0.001), \mathrm{d} 5 \mathrm{~L}$ $(P<0.001)$ and $\mathrm{d} 10 \mathrm{~L}(P=0.001)$ dams (Fig. 9F) and all pregnant dam groups $(F(7,47)=11.104, \quad P<0.001)$. Dams also had significantly shorter $(F(3,24)=15.519$, $P<0.001)$ large intestines at $\mathrm{d} 0 \mathrm{~L}(P<0.001)$ and $\mathrm{d} 5 \mathrm{~L}$ $(P=0.001)$ compared to $\mathrm{d} 25 \mathrm{~L}$ dams, with d0L dams also having shorter large intestines than d10L $(P=0.004)$ dams (Fig. $9 \mathrm{H}$ ). Both the pregnant dams and $\mathrm{d} 5 \mathrm{~L}$ dams had similar large intestine lengths to the proestrus controls (Fig. 9G and $\mathrm{H}$ ).

\section{Gut circumferences were greater in pregnancy and lactation, peaking by $\mathrm{d} 10 \mathrm{~L}$}

Gut circumference measurements for duodenum and ascending colon were greater in the pregnant dams, significantly at $\mathrm{d} 4 \mathrm{P}(F(7,49)=4.108 ; 5.906, P<0.001)$ compared with proestrus controls, with only descending colon values similar (Fig. 10A). Between the different pregnant groups, neither the duodenum nor descending colon tissue circumferences differed; however, ascending colon circumference was significantly wider $(F(2,18)=3.953, P=0.038)$ in early pregnant $\mathrm{d} 4 \mathrm{P}$ dams compared with $\mathrm{d} 12 \mathrm{P}$ dams $(P=0.033)$, which coincided with reduced large intestine length in $\mathrm{d} 12 \mathrm{P}$ rats. $\mathrm{d} 4 \mathrm{P}$ and $\mathrm{d} 18 \mathrm{P}$ rats also had wider $\mathrm{AC}$ values than $\mathrm{d} 25 \mathrm{~L}$ rats (Fig. $10 \mathrm{~A}$ and $\mathrm{B}$ ).

Lactating dams at d10 had larger duodenum circumferences than proestrus controls (Fig. 10B), at the same time as the small and large intestine growth increases at d10L (Fig. 9). By late lactation/weaning duodenum circumference $(F(3,24)=3.052, \quad P=0.048)$ had significantly reduced by $\mathrm{d} 25 \mathrm{~L}$ from the earlier peak at d10L $(P=0.046)$.

Ascending colon circumference $(F(3,24)=6.506$, $P=0.002)$ was also significantly increased in early, compared to late lactation: $\mathrm{dOL}(P=0.045), \mathrm{d} 5 \mathrm{~L}$ $(P=0.035)$ and peaked in $\mathrm{d} 10 \mathrm{~L} \quad(P=0.001)$ dams compared to $\mathrm{d} 25 \mathrm{~L}$ dams and proestrus controls (Fig. 10B). The reduction in late lactation coincided with peak large intestine increases (Fig. 9).

Circumference of descending colon $(F(3,24)=4.346$, $P=0.014$ ) was also significantly smaller in $\mathrm{d} 25 \mathrm{~L}$ than in d10L $(P=0.012)$ dams. Both ascending and descending circumferences at $\mathrm{d} 25 \mathrm{~L}$ were reduced compared to earlier in lactation and were also smaller than proestrus controls - this coincided with the large intestine peak mass and length increases at $\mathrm{d} 25 \mathrm{~L}$.

\section{Discussion}

This is the first study to analyse total orexigenic ghrelin, anorexigenic PYY and GLP-1, in matched fed and fasted plasma and gut tissues, with samples taken during the nocturnal, active phase. We provide new and updated information about organ remodelling in dams, including changes to Gl capacity and tissue sizes, matched with peripherally circulating and tissue concentrations of ghrelin, PYY and GLP-1.

Ghrelin stimulates appetite, thus is expected to increase during pregnancy. However, fasted plasma ghrelin was decreased between $\mathrm{d} 4 \mathrm{P}$ and $\mathrm{d} 18 \mathrm{P}$, consistent with animal (Shibata et al. 2004) and human studies (Fuglsang et al. 
2005, Tham et al. 2009). Suppression of this appetitestimulating signal occurred throughout pregnancy for reasons unknown, and despite ghrelin-secreting cell increases by $\mathrm{d} 12 \mathrm{P}$ compared with proestrus controls that continued until the onset of lactation. Unknown mechanisms underlie peripheral ghrelin suppression during early pregnancy, although increasing leptin may be involved later. What initiates and supports early pregnancy hyperphagia if the only peripheral orexigenic hormone is not involved? These observations caution against endogenous appetite hormone use as body mass control therapies during pregnancy until established that alterations are not harmful to developing embryos.

Reduction in food intake before birth followed low systemic ghrelin at $\mathrm{d} 18 \mathrm{P}$, and the $100 \%$ increase post-partum occurred after peak ghrelin-IR cells and the highest stomach ghrelin measured. Fasted plasma ghrelin increased from early to d25 lactation; dams had $20 \%$ higher than proestrus controls. Shibata et al. (2004) reported no changes to fed plasma ghrelin in rats between d5L and d15L, and Suzuki et al. (2014) likewise found no difference in fed acyl ghrelin. The plasma differences we report are novel and arguably more reliable, as samples were both fasted and taken in the more physiologically relevant dark phase. Late lactation ghrelin increases could be explained by decreased WAT/reduced leptin (Woodside et al. 2000, Taylor et al. 2009), which in turn could unsuppress circulating ghrelin (Ueno et al. 2004). Dams still need to eat more to replenish energy reserves following weaning (very low WAT masses d25L), despite body mass increases (see later discussion). Dams had larger stomach masses by lactation end, with potentially more ghrelin-secretory cells following the measured increase at parturition, contributing to higher circulating ghrelin by d25L.

PYY was not altered during pregnancy, agreeing with Valsamakis et al. (2010), although values were higher than in non-pregnant. Fasted plasma PYY was 63\% higher than controls at $\mathrm{d} 10 \mathrm{~L}$, demonstrating elevated peripheral concentrations, following earlier peaks in $\mathrm{d} 5 \mathrm{~L}$ colon tissue. Other studies report plasma PYY fed and fasted d5L peaks (Tovar et al. 2004, Taylor et al. 2009, Suzuki et al. 2014). Together, these studies indicate that fed/fasting status of ad lib fed dams does not diminish observed PYY peaks. During lactation, AC and DC PYY peaked in $\mathrm{d} 5 \mathrm{~L}$ dams, similar to $\mathrm{d} 5 \mathrm{~L}$ plasma peaks (Taylor et al. 2009, Suzuki et al. 2014). Despite gut region/timing differences between studies, increases were consistent. It remains to be established why a purported satiety hormone elevates during physiological states of hyperphagia; some explanations relating to GI remodelling are explored below.

GLP-1 is a satiety hormone and decreases in insulinresistant states (Toft-Nielsen et al. 2001, Muscelli et al. 2008, Lim et al. 2009). Pregnancy-associated insulin resistance could explain decreases in fasted plasma GLP-1 throughout pregnancy, with lowest values by
d18P. As with PYY, there were unexpected increases, as fed GLP-1 was greatly elevated $(25 x)$ in pregnancy and highest in d18P AC tissue. Likewise, fed GLP-1 was also very high with $\mathrm{d} 0$ and $\mathrm{d} 5$ peaks in lactation; the main source of circulating GLP-1 was likely AC, as DC was very low after $\mathrm{d} 5 \mathrm{~L}$. In contrast, human studies found no GLP-1 lactational changes (Larson-Meyer et al. 2016).

The current study found both PYY and GLP-1, so-called 'satiety' hormones, to be increased, with high values persistent in lactation despite food intake increasing $199 \%$ by d5L. High sustained PYY and GLP-1 may initiate the ileal brake mechanism (Lin et al. 1996, Maljaars et al. 2008), against a low ghrelin background and reduced gastric emptying (Levin et al. 2006), thus slowing gut transit times to allow digestion and nutrient extraction from increased feed. The currently accepted role of PYY and GLP-1 is to rise in response to intake and signal fullness, causing a compensatory appetite reduction but the opposite occurred in pregnant and lactating dams, despite hyperphagia (except briefly at parturition).

This study also investigated physical gut changes to help explain contradictory 'appetite' hormone observations. Following birth, dam body mass increased although WAT reserves decreased, reflecting body composition changes. We explored Gl tract remodelling and have described a number of modifications that show how dam physiology altered to accommodate lactational demands of eight growing pups. Neither stomach nor caecum mass changed across pregnancy, but wet masses increased by end of lactation, consistent with previous studies (Cripps \& Williams 1975, Taylor et al. 2009). Small intestine wet weight and length increased between $\mathrm{d} 4 \mathrm{P}$ and $\mathrm{d} 18 \mathrm{P}$, by 20 and $15 \%$. This increase in size and capacity could be an early, rapid adaptation to increase absorption of nutrients from more food, to support the production of reproductive tissues, also building reserves for lactation. Lactating dams had further increased small intestine wet weight and length by $\mathrm{d} 10 \mathrm{~L}, 50 \%$ longer than non-pregnant controls. Large intestine mass increased with pregnancy and was even heavier by $\mathrm{d} 25 \mathrm{~L}$, in agreement with Cripps and Williams (1975). Any variation in adaptive changes between studies is likely due to differences in diet composition and food quantities consumed. In our study, there was consistency of timing of $\mathrm{SI}$ and $\mathrm{LI}$ tissue expansion with increased stomach and caecum masses, although SI increases peaked earlier at d10 of lactation, whereas LI growth continued to $\mathrm{d} 25 \mathrm{~L}$.

Gut circumferences provided further novel information. Although neither duodenum nor DC were different between pregnancy stages, AC circumferences were. Changes along the Gl tract could be an additional mechanism to support pregnancy/lactation, increasing surface area and gut capacity to process nutrients from more food, altering transit times. Day 4P dams had largest AC circumferences, with higher values in 
duodenum and DC, compared to controls. These data may reflect the earliest pregnancy adaptation to rapidly increase capacity, especially of caecum to hold more food (as microbiome composition changes: Mann et al. 2018), prior to gut lengthening later in pregnancy, further increasing surface area. In early pregnancy, there are less competing demands for space between gravid uterus and abdominal organs, making temporary expansion possible.

In lactating dams, duodenum, AC and DC had increased circumferences leading up to d10L peaks, with decreases from d10L to d25L. Narrowing of colon circumferences coincided with maximal tissue hypertrophy - increased lengths and masses - and capacity, which may reflect final adjustments to maximal feed intakes during lactation. Thus, in addition to later gut hypertrophy, early maternal adaptations to hyperphagia included widening/dilation of specific portions of Gl tract to accommodate greater volumes of food and aid nutrient acquisition. In lactating rats on restricted diets, Campbell and Fell (1964) found SI was similarly dilated, with only partial hypertrophy compared to ad lib fed. That study also reported that the absorptive capacity of SI did not differ between nulliparous and lactating rats with varying gut hypertrophy, suggesting changes are proportionate to requirements. Datta et al. (1995) also reported that food restriction prevented SI hypertrophy and Tovar et al. (2004) found a 30\% food restriction completely suppressed pregnancy-associated PYY rises. Combined, these findings indicate both physical (food mass) and hormonal (PYY/GLP-1) stimulation are needed to initiate and maintain gut growth, as has been expounded in this study, where extensive organ remodelling, with increases in $\mathrm{SI}$ and $\mathrm{LI}$ masses and lengths, occurred during later lactation, coincident with elevations of and following PYY and GLP-1 peak concentrations that had occurred earlier in lactation.

PYY and GLP-1 are co-secreted, with GLP-2 (Mojsov et al. 1986) and have previously been linked with gut growth in adult female mice (PYY: Gomez et al. 1995), male mice (Drucker et al. 1996) and rats (GLP-2 > GLP1: Ghatei et al. 2001). PYY and GLP-2 cause substantial intestinal hypertrophy, with smaller GLP-1 increases. Our findings of gut hypertrophy under conditions of high PYY and very high GLP-1 concentrations highlight that it is imperative to further elucidate the role of L-cells and their secretory products after gut surgeries for body mass reduction, as these techniques lead to rapidly increased concentrations of appetite hormones (Chandarana et al. 2011) and may be stimulating intestinal growth in attempts to regenerate remaining gut tissues (le Roux et al. 2010).

This study has revealed that when maternal nutritional requirements are highest, additional and unexpected supportive changes to increased intake occur in 'appetite' hormones PYY and GLP-1. These hormonal alterations are likely to be homeorhetic adjustments (Bauman \& Currie 1980) to pregnancy, and especially lactation, which have a more pronounced influence on GI remodelling, than satiety. The observed structural changes contribute towards meeting dam enhanced energy requirements and maximising nutrient recovery from the increased intake of pregnancy and more extreme hyperphagia of lactation. They may aid feeding efficiency via altered metabolism and nutrient uptake, slowing food passage rate (Hammond 1997) and facilitate caecum microbe diversity changes (Mann et al. 2018). Our observations show how gut adaptations continue until (and possibly persist beyond) weaning, in rat dams that raise litters of eight pups.

In conclusion, despite hyperphagia, fasted plasma ghrelin was suppressed in pregnancy, although ghrelin-IR cells and stomach ghrelin were highest at birth, supporting onset of lactation-associated hyperphagia. Plasma fed GLP-1 was elevated during pregnancy, and increases of colon PYY and GLP-1 during early lactation were associated with Gl expansion, not satiety. All three 'appetite' hormones were altered in unexpected ways, with important implications for any surgical or pharmaceutical interventions designed to act as weight-control measures, in reproductive age females. Extensive stomach, caecum and gut expansion and remodelling coincided with PYY and GLP-1 peaks. Then increased intestinal masses, lengths and circumferences followed, with peaks at d10L for SI and d25L for LI. These modifications demonstrate how lactating rats process and assimilate more food to support eight pups to weaning. More important questions arise, including what implications may be for future maternal health if $\mathrm{Gl}$ expansion persists, as modifications could accelerate future nutrient assimilation and storage, leading to longterm body mass retention. Also, whether the increased incidence of obesity and insulin resistance in younger human populations may additionally amplify maternal adaptations, thus influencing metabolic programming and future health of any offspring.

\section{Declaration of interest}

V J T served on the Council of Management for the Society for Reproduction and Fertility (SRF) 2013-2016. M L J was Postdoc representative on SRF Council of Management 20172019. M L J was the winning recipient of the SRF Post Doctoral Scientist Prize talk based on this work: Johnson M L, Saffrey M J and Taylor V J (2015) Hyperphagia of pregnancy and lactation is associated with changes in appetite-regulating hormones and gastrointestinal modifications in Wistar rats. Society for Reproduction and Fertility Annual Conference 2015, 20-22 July 2015, St Catherine's College, Oxford, UK. A repeat talk was given at the Annual Meetings of the Endocrine Society of Australia and Society for Reproductive Biology (SRB) and Australia and New Zealand Bone and Mineral Society 2016, 21-24 August 2016, Gold Coast, Australia under the SRF/SRB reciprocal prize scheme. 


\section{Funding}

This work was supported by the School of Life, Health and Chemical Sciences, The Open University.

\section{Acknowledgements}

The authors thank Steve Walters, Karen Evans, Agata Stramek and Sophie Brooks for outstanding technical support and Professor Paul Garthwaite for statistical guidance with the GLM models and data analysis. They are also grateful to the Society for Reproduction and Fertility (SRF) for awarding the Post Doctoral Talk 2015 Prize for this work and funding the reciprocal exchange talk to SRB, Australia.

\section{References}

Bauman DE \& Currie WB 1980 Partitioning of nutrients during pregnancy and lactation: a review of mechanisms involving homeostasis and homeorhesis. Journal of Dairy Science 63 1514-1529. (https://doi. org/10.3168/jds.S0022-0302(80)83111-0)

Boyne R, Fell BF \& Robb I 1966 The surface area of the intestinal mucosa in the lactating rat. Journal of Physiology 183 570-575. (https://doi. org/10.1113/jphysiol.1966.sp007884)

Brubaker PL, Izzo A, Hill M \& Drucker DJ 1997 Intestinal function in mice with small bowel growth induced by glucagon-like peptide-2. American Journal of Physiology 272 E1050-E1058. (https://doi.org/10.1152/ ajpendo.1997.272.6.E1050)

Burdett K \& Reek C 1979 Adaptation of the small intestine during pregnancy and lactation in the rat. Biochemical Journal 184 245-251. (https://doi.org/10.1042/bj1840245)

Campbell RM \& Fell BF 1964 Gastro-intestinal hypertrophy in the lactating rat and its relation to food intake. Journal of Physiology 171 90-97. (https://doi.org/10.1113/jphysiol.1964.sp007363)

Chandarana K, Gelegen C, Karra E, Choudhury AI, Drew ME, Fauveau V, Viollet B, Andreelli F, Withers DJ \& Batterham RL 2011 Diet and gastrointestinal bypass-induced weight loss: the roles of ghrelin and peptide YY. Diabetes 60 810-818. (https://doi.org/10.2337/db10-0566)

Crean GP \& Rumsey RD 1971 Hyperplasia of the gastric mucosa during pregnancy and lactation in the rat. Journal of Physiology 215 181-197. (https://doi.org/10.1113/jphysiol.1971.sp009464)

Cripps AW \& Williams VJ 1975 The effect of pregnancy and lactation on food intake, gastrointestinal anatomy and the absorptive capacity of the small intestine in the albino rat. British Journal of Nutrition 33 17-32. (https://doi.org/10.1079/BJN19750005)

Datta UK, Datta AN \& Mukherjee S 1995 Role of hyperphagia in structural changes of small intestine during lactation. Indian Journal of Physiology and Pharmacology 39 259-262.

Denis RG, Bing C, Brocklehurst S, Harrold JA, Vernon RG \& Williams G 2004 Diurnal changes in hypothalamic neuropeptide and SOCS3 expression: effects of lactation and relationship with serum leptin and food intake. Journal of Endocrinology 183 173-181. (https://doi. org/10.1677/joe.1.05659)

Drucker DJ, Erlich P, Asa SL \& Brubaker PL 1996 Induction of intestinal epithelial proliferation by glucagon-like peptide 2. PNAS 93 7911-7916. (https://doi.org/10.1073/pnas.93.15.7911)

Feder HH 1981 Estrous cyclicity in mammals. In Neuroendocrinology of Reproduction: Physiology and Behavior, pp 279-285. Ed NT Adler. Boston, MA: Springer. (https://doi.org/10.1007/978-1-4684-3881-9_10)

Fuglsang J, Skjaerbaek C, Espelund U, Frystyk J, Fisker S, Flyvbjerg A \& Ovesen P 2005 Ghrelin and its relationship to growth hormones during normal pregnancy. Clinical Endocrinology 62 554-559. (https://doi. org/10.1111/j.1365-2265.2005.02257.x)

Ghatei MA, Goodlad RA, Taheri S, Mandir N, Brynes AE, Jordinson M \& Bloom SR 2001 Proglucagon-derived peptides in intestinal epithelial proliferation: glucagon-like peptide-2 is a major mediator of intestinal epithelial proliferation in rats. Digestive Diseases and Sciences $\mathbf{4 6}$ 1255-1263. (https://doi.org/10.1023/A:1010615429639)
Gomez G, Zhang T, Rajaraman S, Thakore KN, Yanaihara N, Townsend CM, Thompson JC \& Greeley GH 1995 Intestinal peptide YY - ontogeny of gene-expression in rat bowel and trophic actions on rat and mouse bowel. American Journal of Physiology 268 G71-G81. (https://doi. org/10.1152/ajpgi.1995.268.1.G71)

Hammond KA 1997 Adaptation of the maternal intestine during lactation. Journal of Mammary Gland Biology and Neoplasia 2 243-252. (https:// doi.org/10.1023/A:1026332304435)

Johnson ML, Saffrey MJ \& Taylor VJ 2016 Plasma ghrelin concentrations were altered with oestrous cycle stage and increasing age in reproductively competent Wistar females. PLOS ONE 11 e0166229. doi:10.1371/journal.pone.0166229.

Larson-Meyer DE, Schueler J, Kyle E, Austin KJ, Hart AM \& Alexander BM 2016 Do lactation-induced changes in ghrelin, glucagon-like peptide-1, and peptide YY influence appetite and body weight regulation during the first postpartum year? Journal of Obesity 2016 7532926. (https://doi. org/10.1155/2016/7532926)

le Roux CW, Borg C, Wallis K, Vincent RP, Bueter M, Goodlad R, Ghatei MA, Patel A, Bloom SR \& Aylwin SJB 2010 Gut hypertrophy after gastric bypass is associated with increased glucagon-like peptide 2 and intestinal crypt cell proliferation. Annals of Surgery 252 50-56. (https:// doi.org/10.1097/SLA.0b013e3181d3d21f)

Levin F, Edholm T, Schmidt PT, Grybäck P, Jacobsson H, Degerblad M, Höybye C, Holst JJ, Rehfeld JF, Hellström PM et al. 2006 Ghrelin stimulates gastric emptying and hunger in normal-weight humans. Journal of Clinical Endocrinology and Metabolism 91 3296-3302. (https://doi.org/10.1210/jc.2005-2638)

Lim GE, Huang GJ, Flora N, LeRoith D, Rhodes CJ \& Brubaker PL 2009 Insulin regulates glucagon-like peptide- 1 secretion from the enteroendocrine L cell. Endocrinology 150 580-591. (https://doi. org/10.1210/en.2008-0726)

Lin HC, Zhao XT, Wang L \& Wong H 1996 Fat-induced ileal brake in the dog depends on peptide YY. Gastroenterology 110 1491-1495. (https:// doi.org/10.1053/gast.1996.v110.pm8613054)

Lopez-Luna P, Maier I \& Herrera E 1991 Carcass and tissue fat content in the pregnant rat. Biology of the Neonate 60 29-38. (https://doi. org/10.1159/000243385)

Maljaars PWJ, Peters HPF, Mela DJ \& Masclee AAM 2008 Ileal brake: a sensible food target for appetite control. A review. Physiology and Behavior 95 271-281. (https://doi.org/10.1016/j.physbeh.2008.07.018)

Mann PE, Huynh K \& Widmer G 2018 Maternal high fat diet and its consequence on the gut microbiome: a rat model. Gut Microbes $\mathbf{9}$ 143-154. (https://doi.org/10.1080/19490976.2017.1395122)

Mojsov S, Heinrich G, Wilson IB, Ravazzola M, Orci L \& Habener JF 1986 Preproglucagon gene expression in pancreas and intestine diversifies at the level of post-translational processing. Journal of Biological Chemistry 261 11880-11889.

Muscelli E, Mari A, Casolaro A, Camastra S, Seghieri G, Gastaldelli A, Holst JJ \& Ferrannini E 2008 Separate impact of obesity and glucose tolerance on the incretin effect in normal subjects and type 2 diabetic patients. Diabetes 57 1340-1348. (https://doi.org/10.2337/db07-1315)

Naismith DJ, Richardson DP \& Pritchard AE 1982 The utilization of protein and energy during lactation in the rat, with particular regard to the use of fat accumulated in pregnancy. British Journal of Nutrition 48 433-441. (https://doi.org/10.1079/BJN19820125)

Nakazato M, Murakami N, Date Y, Kojima M, Matsuo H, Kangawa K \& Matsukura S 2001 A role for ghrelin in the central regulation of feeding. Nature 409 194-198. (https://doi.org/10.1038/35051587)

Outeirino-Iglesias V, Romani-Perez M, Gonzalez-Matias LC, Vigo E \& Mallo F 2015 GLP-1 increases preovulatory LH source and the number of mature follicles, as well as synchronizing the onset of puberty in female rats. Endocrinology 156 4226-4237. (https://doi.org/10.1210/ en.2014-1978)

Penzes L \& Regius O 1985 Changes in the intestinal microvillous surface area during reproduction and ageing in the female rat. Journal of Anatomy 140 389-396.

Pujol E, Proenza AM, Roca P \& Lladó I 2006 Changes in mammary fat pad composition and lipolytic capacity throughout pregnancy. Cell and Tissue Research 323 505-511. (https://doi.org/10.1007/s00441-0050085-0)

Reiff T, Jacobson J, Cognigni P, Antonello Z, Ballesta E, Tan KJ, Yew JY, Dominguez M \& Miguel-Aliaga I 2015 Endocrine remodelling of the 
adult intestine sustains reproduction in Drosophila. elife 4 e06930. (https://doi.org/10.7554/eLife.06930)

Ronveaux CC, de Lartigue G \& Raybould HE 2014 Ability of GLP-1 to decrease food intake is dependent on nutritional status. Physiology and Behavior 135 222-229. (https://doi.org/10.1016/j.physbeh.2014.06.015)

Shibata K, Hosoda H, Kojima M, Kangawa K, Makino Y, Makino I, Kawarabayashi T, Futagami K \& Gomita Y 2004 Regulation of ghrelin secretion during pregnancy and lactation in the rat: possible involvement of hypothalamus. Peptides 25 279-287. (https://doi.org/10.1016/j. peptides.2004.01.011)

Speakman JR 2008 The physiological costs of reproduction in small mammals. Philosophical Transactions of the Royal Society of London: Series B, Biological Sciences 363 375-398. (https://doi.org/10.1098/ rstb.2007.2145)

Stengel A, Keire D, Goebel M, Evilevitch L, Wiggins B, Tache Y \& Reeve JR 2009 The RAPID method for blood processing yields new insight in plasma concentrations and molecular forms of circulating gut peptides. Endocrinology 150 5113-5118. (https://doi.org/10.1210/en.2009-0697)

Stramek AK, Johnson ML \& Taylor VJ 2018 Improved timed-mating, noninvasive method using fewer unproven female rats with pregnancy validation via early body mass increases. Laboratory Animals Epub. (https://doi.org/10.1177/0023677218774076)

Suzuki Y, Nakahara K, Maruyama K, Okame R, Ensho T, Inoue Y \& Murakami N 2014 Changes in mRNA expression of arcuate nucleus appetite-regulating peptides during lactation in rats. Journal of Molecular Endocrinology 52 97-109. (https://doi.org/10.1530/JME-13-0015)

Taylor VJ, Patterson M, Ghatei MA, Bloom SR \& Wilson CA 2009 Ghrelin and peptide YY (PYY) profiles in gastrointestinal tissues and the circulation of the rat during pregnancy and lactation. Peptides $\mathbf{3 0}$ 2213-2220. (https://doi.org/10.1016/j.peptides.2009.09.022)

Tham E, Liu JH, Innis S, Thompson D, Gaylinn BD, Bogarin R, Haim A, Thorner MO \& Chanoine JP 2009 Acylated ghrelin concentrations are markedly decreased during pregnancy in mothers with and without gestational diabetes: relationship with cholinesterase. American Journal of Physiology: Endocrinology and Metabolism 296 E1093-E1100. (https://doi.org/10.1152/ajpendo.90866.2008)
Toft-Nielsen MB, Damholt MB, Madsbad S, Hilsted LM, Hughes TE, Michelsen BK \& Holst JJ 2001 Determinants of the impaired secretion of glucagon-like peptide-1 in type 2 diabetic patients. Journal of Clinical Endocrinology and Metabolism 86 3717-3723. (https://doi.org/10.1210/ jcem.86.8.7750)

Tovar SA, Seoane LM, Caminos JE, Nogueiras R, Casanueva FF \& Dieguez C 2004 Regulation of peptide YY levels by age, hormonal, and nutritional status. Obesity Research 12 1944-1950. (https://doi.org/10.1038/ oby.2004.244)

Trujillo ML, Spuch C, Carro E \& Senaris R 2011 Hyperphagia and central mechanisms for leptin resistance during pregnancy. Endocrinology 152 1355-1365. (https://doi.org/10.1210/en.2010-0975)

Ueno N, Dube MG, Inui A, Kalra PS \& Kalra SP 2004 Leptin modulates orexigenic effects of ghrelin and attenuates adiponectin and insulin levels and selectively the dark-phase feeding as revealed by central leptin gene therapy. Endocrinology 145 4176-4184. (https://doi.org/10.1210/ en.2004-0262)

Valsamakis G, Margeli A, Vitoratos N, Boutsiadis A, Sakkas EG, Papadimitriou G, Al-Daghri NM, Botsis D, Kumar S, Papassotiriou I et al. 2010 The role of maternal gut hormones in normal pregnancy: fasting plasma active glucagon-like peptide 1 level is a negative predictor of fetal abdomen circumference and maternal weight change. European Journal of Endocrinology 162 897-903. (https://doi.org/10.1530/EJE-10-0047)

Woodside B, Abizaid A \& Walker C 2000 Changes in leptin levels during lactation: implications for lactational hyperphagia and anovulation. Hormones and Behavior 37 353-365. (https://doi.org/10.1006/ hbeh.2000.1598)

Received 8 August 2018

First decision 17 September 2018

Revised manuscript received 17 January 2019

Accepted 19 February 2019 